\title{
eia)
}

< Countries

\section{South China Sea}

Last Updated: February 7, 2013 (Notes)

full report

\section{Overview}

The South China Sea is a critical world trade route and a potential source of hydrocarbons, particularly natural gas, with competing claims of ownership over the sea and its resources.

Stretching from Singapore and the Strait of Malacca in the southwest to the Strait of Taiwan in the northeast, the South China Sea is one of the most important trade routes in the world. The sea is rich in resources and holds significant strategic and political importance.

The area includes several hundred small islands, rocks, and reefs, with the majority located in the Paracel and Spratly Island chains. Many of these islands are partially submerged land masses unsuitable for habitation and are little more than shipping hazards. For example, the total land area of the Spratly Islands encompasses less than 3 square miles.

Several of the countries bordering the sea declare ownership of the islands to claim the surrounding sea and its resources. The Gulf of Thailand borders the South China Sea, and although technically not part of it, disputes surround ownership of that Gulf and its resources as well.

Asia's robust economic growth boosts demand for energy in the region. The U.S. Energy Information Administration (EIA) projects total liquid fuels consumption in Asian countries outside the Organization for Economic Cooperation and Development (OECD) to rise at an annual growth rate of 2.6 percent, growing from around 20 percent of world consumption in 2008 to over 30 percent of world consumption by 2035. Similarly, non-OECD Asia natural gas consumption grows by 3.9 percent annually, from 10 percent of world gas consumption in 2008 to 19 percent by 2035. ElA expects China to account for 43 percent of that growth.

With Southeast Asian domestic oil production projected to stay flat or decline as consumption rises, the region's countries will look to new sources of energy to meet domestic demand. China in particular promotes the use of natural gas as a preferred energy source and set an ambitious target of increasing the share of natural gas in its energy mix from 3 percent to 10 percent by 2020. The South China Sea offers the potential for significant natural gas discoveries, creating an incentive to secure larger parts of the area for domestic production. 


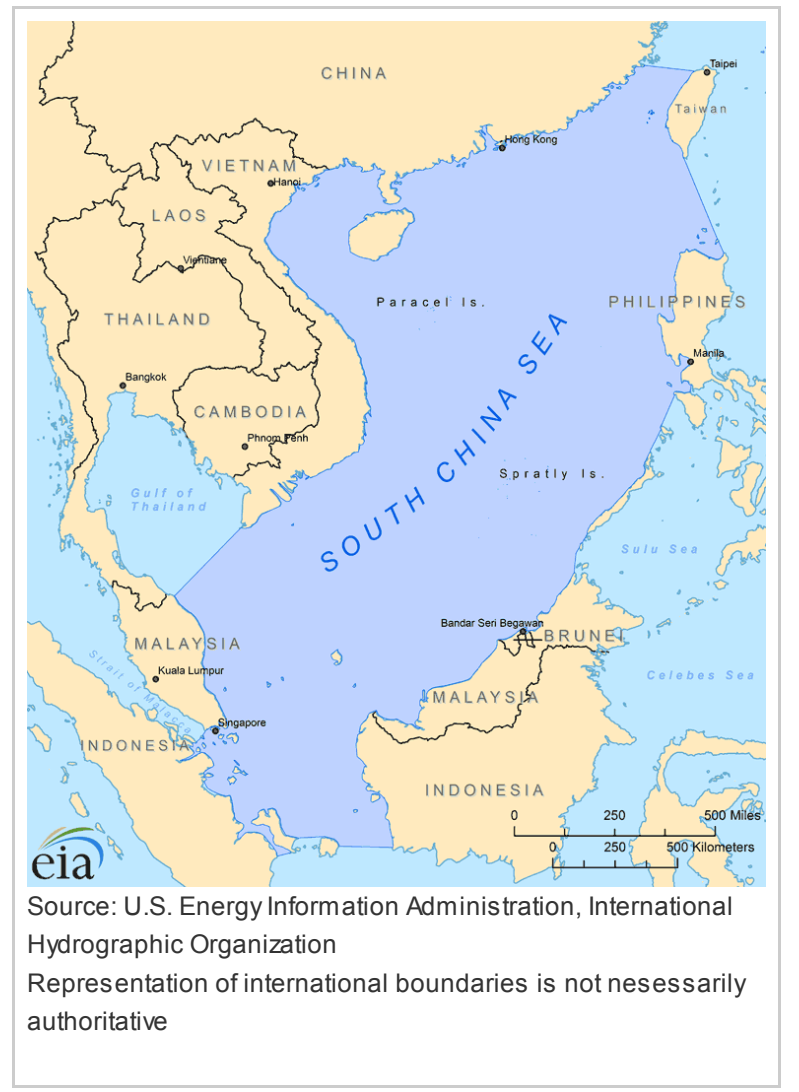

\section{Reserves and resources}

EIA estimates the South China Sea contains approximately 11 billion barrels of oil and 190 trillion cubic feet of natural gas in proved and probable reserves. Conventional hydrocarbons mostly reside in undisputed territory.

It is difficult to determine the amount of oil and natural gas in the South China Sea because of under-exploration and territorial disputes. Most current discovered fields cluster in uncontested parts of the sea, close to the shorelines of the coastal countries. ElA estimates there to be approximately 11 billion barrels (bbl) of oil reserves and 190 trillion cubic feet (Tcf) of natural gas reserves in the South China Sea. These numbers represent both proved and probable reserves, making them closer to a high-end estimate. Energy consultancy Wood Mackenzie, for example, estimates the sea to contain only 2.5 billion barrels of oil equivalent in proved oil and gas reserves.

In addition to proved and probable reserves, the South China Sea may have additional hydrocarbons in underexplored areas. The U.S. Geological Survey (USGS) analyzed the potential for undiscovered conventional oil and gas fields within several geologic provinces of Southeast Asia in 2010 as part of its World Petroleum Resources Assessment Project. The study included a significant area of the South China Sea, which the USGS estimates may contain anywhere between 5 and 22 billion barrels of oil and between 70 and 290 trillion cubic feet of gas in as-yet undiscovered resources (not including the Gulf of Thailand and other areas adjacent to the South China Sea). These additional resources are not considered commercial reserves at this time because it is unclear how economically feasible it would be to extract them.

As the USGS assessment did not examine the entire area, undiscovered resources could be greater. In November 2012, the Chinese National Offshore Oil Company (CNOOC) estimated the area holds around 125 billion barrels of oil and 500 trillion cubic feet of natural gas in undiscovered resources, although independent studies have not confirmed this figure. 

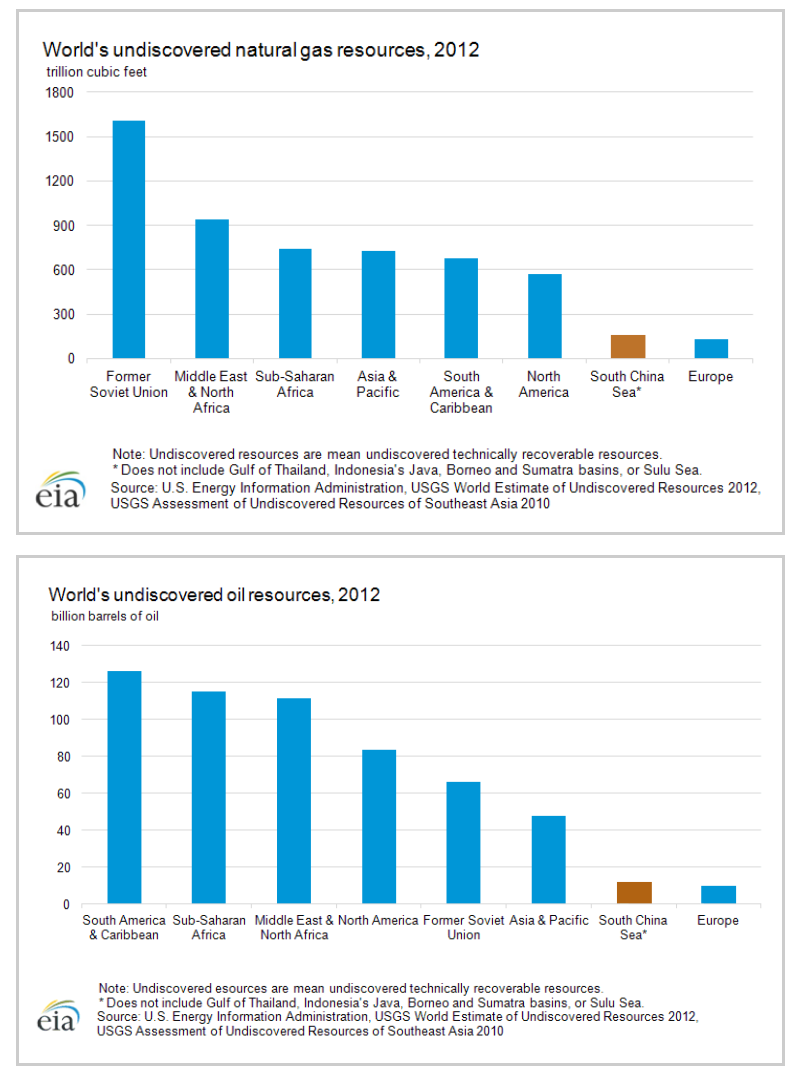

\section{Uncontested areas}

The majority of current reserves exist in shallow water basins on the boundaries of the sea. This situation reflects limited exploration of deepwater areas. Vietnam, Malaysia, and Brunei have a long history of development in the South China Sea. Lacking significant onshore potential, they have invested in offshore technology, pipeline networks, and drilling; foreign partners often provide expertise. Consequently, these countries have the highest oil and gas reserves in the sea.

Over the past few years, however, companies have begun venturing farther offshore in an attempt to find new discoveries to compensate for declining fields. Relatively recent discoveries such as China's Liwan 3-1 gas field, discovered in 2006, demonstrate the potential of deepwater exploration. Chinese national oil companies have built on initial successes in the Pearl River Mouth Basin and are rapidly expanding offs hore activity in an effort to find new reserves and increase production.

Rather than attempting unilateral exploration and production (E\&P) activities in disputed territory, several countries have opted to cooperate in the South China Sea. Malaysia and Brunei settled territorial disputes in 2009 and have partnered to explore offshore Brunei waters. Thailand and Vietnam have jointly developed areas of the Gulf of Thailand, despite ongoing territorial disputes. These success cases contrast with the parts of the South China Sea contested by multiple parties, which have seen little energy development.

\section{South China Sea estimated proved and probable}

\section{reserves}

\begin{tabular}{lcc}
$\begin{array}{l}\text { Country } \\
\text { name }\end{array}$ & $\begin{array}{r}\text { Crude oil and liquids } \\
\text { reserves (billion } \\
\text { barrels) }\end{array}$ & $\begin{array}{r}\text { Natural gas } \\
\text { reserves (trillion } \\
\text { cubic feet) }\end{array}$ \\
\hline Brunei & 1.5 & 15 \\
\hline China & 1.3 & 15 \\
\hline Indonesia & 0.3 & 55 \\
\hline Malaysia & 5.0 & 80 \\
\hline Philippines & 0.2 & 4 \\
\hline Taiwan & - & -1 \\
\hline Thailand & - & 20 \\
\hline Vietnam
\end{tabular}


Note: Reserve totals do not include Gulf of Thailand or onshore reserves.

Reserve estimates are based on field ownership status.

Sources: U.S. Energy Information Administration, Oil \& Gas

Journal, IHS, CNOOC, PFC Energy.

\section{Contested territory}

Spratly Islands

EIA estimates the region around the Spratly Islands to have virtually no proved or probable oil reserves. Industry sources suggest less than 100 billion cubic feet (Bcf) in currently economically viable natural gas reserves exist in surrounding fields. However, the Spratly Island territory may contain significant deposits of undiscovered hydrocarbons. USGS assessments estimate anywhere between 0.8 and 5.4 (mean 2.5) billion barrels of oil and between 7.6 and 55.1 (mean 25.5) Tcf of natural gas in undiscovered resources.

Evidence suggests that most of these resources are likely located in the contested Reed Bank at the northeast end of the Spratlys, which is claimed by China, Taiwan, and Vietnam. The Philippines began exploring the area in 1970 and discovered natural gas in 1976. U.S.based Sterling Energy won the concession in 2002, and U.K.-based Forum Energy acquired the concession in 2005 and became its operator. However, Chinese objections halted further development, and the concession remains undeveloped.

Paracel Islands

The Paracel island territory does not have significant discovered conventional oil and gas fields and thus has no proved or probable reserves. Geologic evidence suggests the area does not have significant potential in terms of conventional hydrocarbons.

\section{Exploration and production}

\section{The South China Sea poses extensive geological, technological, and political challenges to developing hydrocarbon} resources.

While national oil companies (NOCs) have been successful in extracting hydrocarbons near the shorelines of the South China Sea, the majority of the area presents daunting challenges to development. In addition to the geopolitical disputes, the contested areas of the sea face geological and technological concerns.

ElA estimates the South China Sea to be more viable as a source of natural gas than as a source of oil, so producers would have to construct expensive subsea pipelines to carry the gas to processing facilities. Submarine valleys and strong currents present formidable geologic problems to effective deepwater gas infrastructure. The region is also prone to typhoons and tropical storms, precluding cheaper rigid drilling and production platforms. Industry sources point to innovations in deepwater drilling pioneered throughout the Gulf of Mexico as models for developing the South China Sea, including tension leg tethering of production installations and managed pressure drilling to operate in the high-pressure deepwater environment. NOCs have partnered with international companies to provide technology and equipment for deep sea exploration and drilling operations.

\section{South China Sea estimated conventional hydrocarbon production}

Estimated production in South China Sea (2011)

Country

\section{Oil ${ }^{1}$}

Brunei

1000 barrels/day

Natural gas billion cubic feet
Major exploration and production areas

\section{SCS contract holders and operators}

\section{National oil} companies PetroleumBRUNEI

\section{Foreign firms}

BHP Billiton,

ConocoPhillips, Hess Corporation, Kulczyk Oil Ventures, Mitsubishi Corporation, Murphy Oil, PETRONAS, 


\begin{tabular}{|c|c|c|c|c|c|}
\hline & & & & & Brunel, Shell, Iotal \\
\hline China & 250 & 600 & $\begin{array}{l}\text { Pearl River Mouth Basin } \\
\text { Qiongdongnan Basin }\end{array}$ & $\begin{array}{l}\text { CNOOC } \\
\text { Sinopec } \\
\text { CNPC }\end{array}$ & $\begin{array}{l}\text { BG Group, BP, Chevron, } \\
\text { ConocoPhillips, Eni, } \\
\text { ExxonMobil, Husky, } \\
\text { Newfield, Shell, Total }\end{array}$ \\
\hline Indonesia & 60 & 200 & Natuna Basin & PT Pertamina (Persero) & $\begin{array}{l}\text { PetroChina, Chevron, } \\
\text { CNPC, ConocoPhillips, } \\
\text { Eni, ExxonMobil, Husky, } \\
\text { KUFPEC, PETRONAS, } \\
\text { Santos, Statoil, Total }\end{array}$ \\
\hline Malaysia & 500 & 1,800 & $\begin{array}{l}\text { Sabah } \\
\text { Sarawak } \\
\text { Malay Basin (w/ } \\
\text { Thailand) }\end{array}$ & PETRONAS & $\begin{array}{l}\text { Lundin, BHP Billiton, } \\
\text { ConocoPhillips, } \\
\text { ExxonMobil, Hess, } \\
\text { KUFPEC, MDC O\&G, } \\
\text { Murphy Oil, Newfield, } \\
\text { Nippon, Petrofac, Roc } \\
\text { Oil, Shell, Talisman } \\
\text { Energy }\end{array}$ \\
\hline Philippines & 25 & 100 & Palawan Basin & PNOC & ExxonMobil, Shell \\
\hline Thailand & - & - & $\begin{array}{l}\text { Gulf of Thailand } \\
\text { Malay Basin (w/ } \\
\text { Malaysia) }\end{array}$ & PTTEP & $\begin{array}{l}\text { BG Group, Chevron, } \\
\text { Shell }\end{array}$ \\
\hline Vietnam & 300 & 300 & $\begin{array}{l}\text { Cuu Long Basin } \\
\text { Nam Con Son Basin }\end{array}$ & PetroVietnam & $\begin{array}{l}\text { KNOC, ConocoPhillips, } \\
\text { Geopetrol, Premier Oil, } \\
\text { PTTEP, Santos, SK Corp, } \\
\text { Total, Zarubezhneft }\end{array}$ \\
\hline
\end{tabular}

1 Oil production includes lease condensate.

Sources: U.S. Energy Information Administration, Oil \& Gas Journal, IHS, CNOOC, PFC Energy.

Brunei

The Brunei National Petroleum Company (PetroleumBRUNEI) manages offshore activities in the country, while Brunei-Shell Petroleum, a joint venture between Shell and the government, is the sole crude oil producer in the country. Brunei's largest offshore oil and gas field is called Champion, which began production in 1972. The Southwest Ampa gas field accounts for the majority of the country's natural gas production and supplies Brunei's natural gas liquefaction plant in Lumut.

The government prioritizes new exploration activity to counteract Brunei's older declining fields. Exploration has become easier since Malaysia and Brunei formally resolved their offshore territorial dispute in March 2009. PetroleumBRUNEI successfully entered into a production sharing agreement (PSA) with Malaysia's PETRONAS. The two NOCs began drilling in several offshore oil and gas fields off Brunei in 2011 and have proposed investing in an onshore petrochemical plant to cater to export markets.

\section{China}

Along with a growth in onshore gas production, China continues to advance into deepwater areas in the Pearl River Mouth and Qiongdongnan basins in the South China Sea. The country's three largest national oil companies, China National Offs hore Oil Corporation (CNOOC), China Petroleum \& Chemical Corporation (Sinopec), and China National Petroleum Corporation (CNPC), are responsible for developing South China Sea's resources.

CNOOC has the most experience with offshore oil production and has invested the most into the sea. According to its 2011 annual report, CNOOC produced an average of 193,000 barrels per day in the South China Sea for that year. Activities in the South China Sea accounted for around a third of CNOOC's daily production. In May 2011, the company completed the construction of CNOOC 981, the country's most advanced deepwater oil drilling platform to date, for about $\$ 925$ million. CNOOC intends for the rig to increase China's ability to develop offshore resources in the South China Sea.

CNPC and Sinopec are less active in the area, but both companies value the importance of the sea for both upstream and delivery. CNPC largely focuses on offshore drilling activities in the Bohai Bay, which is not in the South China Sea, although it provides offshore drilling equipment to other companies. Sinopec has not invested directly in the South China Sea, but it has expressed interest in deepwater drilling in the Qiongdongnan Basin off Hainan Island. 
CNOOC signed its first contract with foreign companies on offs hore activity in the South China Sea in 1983, allowing BP, Petrobras, Petro-Canada, and BHP Billiton to develop several blocks jointly in the mouth of the Pearl River Basin. In recent years, CNOOC has signaled plans to invest in exploring the South China Sea with foreign companies and has opened dozens of offshore bidding blocks. In 2011, CNOOC offered 19 bidding blocks, mostly in the Pearl River Mouth Basin of the South China Sea. Despite several recent awards to foreign firms, CNOOC has not been able to award the majority of the blocks because of overlapping territorial claims with Vietnam and limited availability of geologic data.

Under Chinese law, CNOOC may acquire a 51-percent stake in any joint venture in the event of commercial discovery. Chevron and Eni work with CNOOC in the CACT Operators Group on offs hore oilfields in South China Sea. CNOOC signed an agreement with Husky Energy in 2010 for the latter to explore the deepwater gas discovery in the Liuhua (LH 29-1) field in the Pearl River Basin. Husky also approved development of the Liwan 3-1 gas field southeast of Hong Kong, discovered in 2006 and the first major Chinese discovery in the South China Sea. Liwan has an estimated 4 to 6 trillion cubic feet (Tcf) in proved and probable reserves, and Husky expects output of up to 110 billion cubic feet (Bcf) per year starting in 2014. CNOOC has not offered any plans to drill in the contested Spratly Islands area.

\section{Indonesia}

Indonesia's oldest and largest producing oil fields, including Duri and Minas, are mostly located offshore east and south Sumatra outside the South China Sea. Similarly, most natural gas reserves are located near the Arun field in Aceh or Bada field in East Kalimantan, also outside the South China Sea. In addition, Indonesia has been reorienting oil and gas production to meet domestic demand, rather than for exports. Consequently, Indonesia's upstream industry currently plays a limited role in South China Sea production.

At the same time, PT Pertamina, Indonesia's national oil company, has attempted to gain more stakes in South China Sea fields, such as Natuna's D-Alpha Block and offshore blocks near Vietnam in the Nam Con Son basin. The company hopes to offset declining fields with new discoveries in the region through joint exploration with PetroVietnam and PETRONAS.

\section{Malaysia}

The state's NOC, PETRONAS, holds most of the country's oil and gas assets and is Malaysia's biggest domestic oil and gas producer. The company's Peninsular Gas Utilization (PGU) system, composed of six processing plants and 1,500 miles of pipeline, forms a key link to offshore gas development in the South China Sea. Malaysia hopes to expand its LNG regasification capacity to boost exports to regional markets.

Malaysia has several greenfield deepwater projects (i.e., no existing infrastructure) with international oil companies underway in the Pacific Ocean in the Sabah and Sarawak basins that the country hopes will offset declining domestic production and contribute to regional LNG exports. ExxonMobil is the country's biggest foreign oil and gas producer, at around 50,000 barrels per day, with Royal Dutch Shell and Hess continuing to invest in enhanced oil recovery (EOR) for existing fields and new drilling.

Malaysia and Thailand agreed to develop a section of the Gulf of Thailand jointly without either party ceding legal rights to it. This Joint Development Area (JDA) is an important source of Malaysian gas exports, estimated at around 1 Tcf production in 2012.

\section{Philippines}

Shell operates the Malampaya gas platform located in the northern Palawan basin in a joint venture with Chevron and the Philippine National Oil Company (PNOC). Commercial drilling began in October 2001 with a reserve base of 2.7 Tcf and 85 million barrels of condensate. It is the flagship project of the country's Department of Energy and provides power for domestic use.

The Philippines had begun exploring the Reed Bank area of the Spratly Islands in the 1970 s and successfully tested a gas well in 1976. Before commercial drilling began, Chinese protests forced the operation to shut down. 


\section{Thailand}

About 80 percent of Thailand's crude oil production comes from offshore fields in the Gulf of Thailand. Chevron is the largest oil producer in Thailand, accounting for nearly 70 percent of the country's crude oil and condensate production in 2011. The largest oilfield is Chevron's Benjamas field located in the north Pattani Basin. The field's production peaked in 2006 and declined to less than $30,000 \mathrm{bbl} / \mathrm{d}$ in 2010 . Independent companies such as Salamander Energy and Coastal Energy have made smaller discoveries in recent years, such as Bualuang, Songkhla, and Bua Ban.

The majority of gas production is located in the Pattani Basin in the Gulf of Thailand. PTT (the country's partially-privatized NOC), Total, and BG Group have stakes in Thailand's largest producing field located in the basin, named Bongkot. The field has averaged production rates of around 220 Bcf per year for the past several years. The MalaysiaThailand Joint Development Area (JDA), located in the lower part of the Gulf of Thailand and northern part of the Malay Basin, is also a large contributor of natural gas supplies to Thailand.

\section{Vietnam}

Vietnam hopes to expand offshore production in the South China Sea as a way of meeting domestic demand and contributing to state finances. Because of this, the government awarded a large number of contracts to foreign firms and began investing in LNG regasification capacity.

Vietnam's NOC PetroVietnam holds responsibility for all oil and gas E\&P, storage, processing, and distribution. It accounts directly for 20 percent of the country's oil production and half of gas production, along with serving as partner to international companies in almost all new developments and refinery projects. Although it is moving slowly towards privatization, PetroVietnam still orchestrates major E\&P activities in the South China Sea.

Because of the government's push to award foreign contracts, major foreign oil companies have a strong presence in Vietnam's offshore production in production-sharing contracts (PSCs) with PetroVietnam. Chevron has operated offshore Vietnam since 1996 and expanded its operations after acquiring Unocal in 2005. The company currently operates three PSCs in the Cuu Long and Phu Khanh Basins and estimates around 5 Tcf in proved and probable reserves offshore Vietnam. French independent Perenco surpassed ConocoPhillips as the largest energy investor in Vietnam in 2012 after buying out the U.S. company's Vietnam assets, including six offshore blocks in the South China Sea.

PetroVietnam also partners with smaller foreign ventures to develop offshore fields, both in the South China Sea and Gulf of Thailand. Italy's Eni has three 50-percent stakes in offshore Vietnam blocks, most recently from July 2012 in Block 114 in the Song Hong Basin, which industry sources estimate contains 10 percent of Vietnam's hydrocarbon resources.

Smaller companies, particularly from neighboring South Korea, China, and Singapore, have organized into several joint operating companies to develop offshore blocks, particularly near the Malaysian border. These companies produce close to $100,000 \mathrm{bbl} / \mathrm{d}$ in aggregate.

In June 2012, CNOOC offered nine oil and gas blocks to foreign bidders in a part of the South China Sea overlapping with Vietnam's 200-mile exclusive economic zone in the Jiannan and Wan'an Basins. The Vietnam government disapproved of the offer, and no foreign firms have bid on blocks. The contested area contains no discoveries, although PetroVietnam announced that it was operating in the area in cooperation with India's ONGC Videsh Limited, Russia's Gazprom, and ExxonMobil.

\section{Singapore}

Singapore is a major transit point and a refining center in the region. Singapore has a crude refining capacity of 1.4 million bbl/d, according to the Oil \& Gas Journal. Crude coming east from the Strait of Malacca and intra-sea trade is refined and sent forward as petroleum products to the major energy consumers in Asia. At the same time, the NOC Singapore Petroleum Company aims to become a significant regional producer and has acquired rights to exploration blocks in the Gulf of Thailand, the Pearl River Mouth basin, and offshore Indonesia. 


\section{Global trade}

More than half of the world's annual merchant fleet tonnage passes through the Straits of Malacca, Sunda, and Lombok, with the majority continuing on to the South China Sea. Almost a third of global crude oil and over half of global LNG trade passes through the South China Sea, making it one of the most important trade routes in the world.

Eastbound maritime trade through the South China Sea passes through the Straits of Malacca, Sunda, and Lombok, although there are few detailed sources on traffic volume. A 2006 study by Japan's Ministry of Land, Infrastructure, and Transport (MLIT) estimated that almost 94 thousand vessels of 100 gross tonnage or greater passed through the Strait of Malacca in 2004 out of 607 thousand global ocean going vessel movements, or 15 percent of the world's total. Of these, 32 percent were container vessels, 25 percent were tanker vessels, 15 percent were cargo vessels, and 15 percent were bulk carriers, with the remainder LNG and other ships.

A follow-up survey in late 2007 estimated 117 thousand vessels would pass through Malacca in 2010 with a total deadweight of 4.7 billion metric tons. The United Nations Conference on Trade and Development (UNCTAD) Review of Maritime Transport 2011 estimated 8.4 billion tons of total world maritime trade in 2010 . This volume suggests more than half of the world's annual merchant fleet tonnage passed through the Straits of Malacca, Sunda, and Lombok in 2010

With Asia's growing energy demand, ElA expects a greater share of oil from producers in the Persian Gulf and Africa to pass through the South China Sea. In addition, Asian countries are investing in new exploration and development of natural gas resources in the region, increasing the share of global LNG trade.

\section{Crude oil}

Approximately 14 million barrels of crude oil pass through the South China Sea and Gulf of Thailand per day, or almost a third of global oil movement, according to data from Lloyd's List Intelligence tanker-tracking service and GTIS Global Trade Atlas. Over 90 percent of the total flow comes from the Strait of Malacca, while the rest comes from intra-Southeast Asia regional trade.

First, approximately 15.2 million barrels per day (MMbbl/d) of oil passed through the Strait of Malacca in 2011, the shortest sea route between African and Persian Gulf suppliers and Asian markets (see World Oil Transit Chokepoints). A significant amount of crude arriving in the strait (1.4 MMbbl/d) goes to terminals in Singapore and Malaysia, where it is processed and shipped out again as refined petroleum products. Next, the rest of the flow (12.8 million $\mathrm{MMbbl} / \mathrm{d}$ ) continues on through the South China Sea to China and Japan (4.5 and 3.2 $\mathrm{MMbbl} / \mathrm{d}$, respectively), the two largest energy consumers in Asia. Finally, around 15 percent of oil moving through the South China Sea goes on to the East China Sea, mostly to South Korea (see East China Sea regional brief).

Crude oil flow in the South China Sea also comes from Intra-Southeast Asia regional trade, particularly from Malaysian ( $0.4 \mathrm{MMbbl} / \mathrm{d})$, Indonesian $(0.3 \mathrm{MMbbl} / \mathrm{d})$, and Australian $(0.2$ $\mathrm{MMbbl} / \mathrm{d}$ ) oil exports. Intra-regional trade is approximately equally distributed between Singapore, South Korea, Japan, and China, with smaller amounts going to other Southeast Asia countries. A fifth of intra-regional crude oil flow, the most for any importer, goes to Singapore for refining. Around $0.2 \mathrm{MMbbl} / \mathrm{d}$ of crude oil pass south through the Strait of Lombok on to Australia and the Pacific.

South China Sea major crude oil trade flows, 2011 


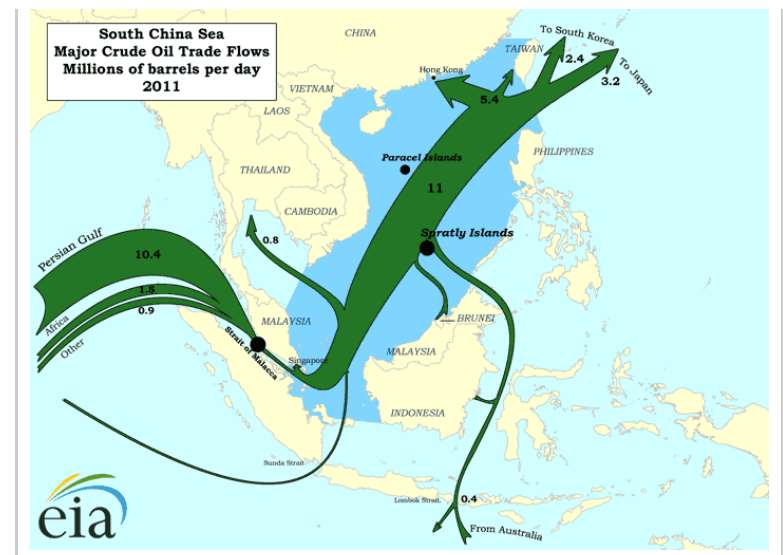

Sources: U.S. Energy Information Administration, Lloyd's List Intelligence, GTI Global Trade Atlas, Center for Naval Analyses.

\section{Liquefied natural gas}

EIA estimates that around 6 trillion cubic feet (Tcf) of liquefied natural gas (LNG), or over half of global LNG trade, passed through the South China Sea in 2011, using data from PFC Energy and Cedigaz. Around 56 percent of this volume ( $3.4 \mathrm{Tcf}$ ) continued on as imports to Japan, 24 percent to South Korea (1.4 Tcf), 19 percent to China and Taiwan (0.6 and 0.6 Tcf respectively), and the rest to other regional countries. The biggest exporter through the sea was Qatar with 1.2 Tcf. Together, Qatar, Malaysia, Indonesia, and Australia accounted for almost 75 percent of all LNG exports to the region.

Following the Fukushima crisis, Japan increased its LNG imports. In the first half of 2012, the South China Sea area accounted for about 58 percent of global LNG trade, according to data from PFC Energy. With growing natural gas demand in East Asia, EIA projects the South China Sea's share of global LNG trade to increase in coming years. Much of the new supply will come through the Strait of Malacca, although countries like Singapore and Indonesia are investing in new regasification plants fed from gas fields in the South China Sea to increase their LNG export capacity.

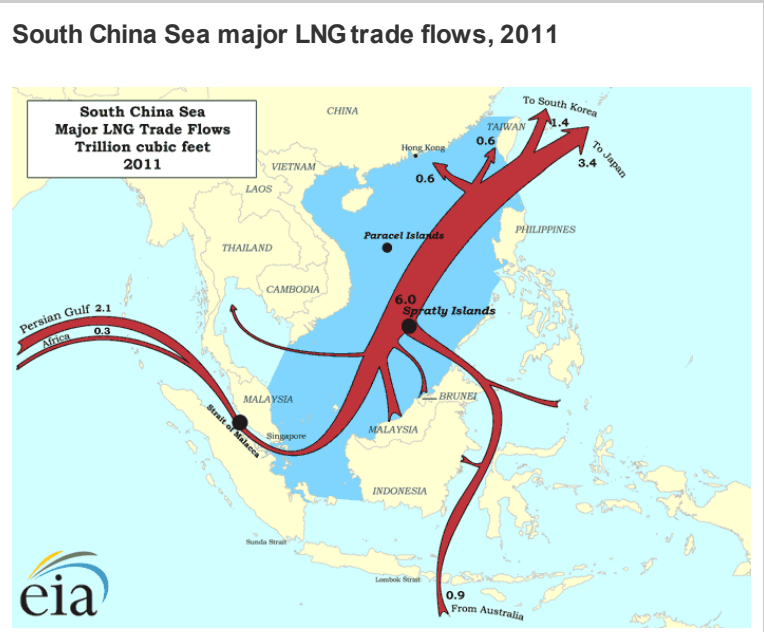

Sources: U.S. Energy Information Administration; Cedigaz; PFC Energy.

\section{Legal status and territorial claims}

There are many competing claims over the South China Sea and its resources by several Asian countries. To date, there has been no international resolution of these disputes.

The South China Sea historically has been a source of conflict among its states. Fishing boats from one country are harassed by other claimants, occasionally resulting in civilian fatalities. Companies permitted to explore for oil and natural gas by one country have been 
denied access to disputed areas by armed ships of other claimants. Military skirmishes have periodically occurred among the coastal countries, the most serious in 1974 when China captured the Paracel Islands from Vietnam.

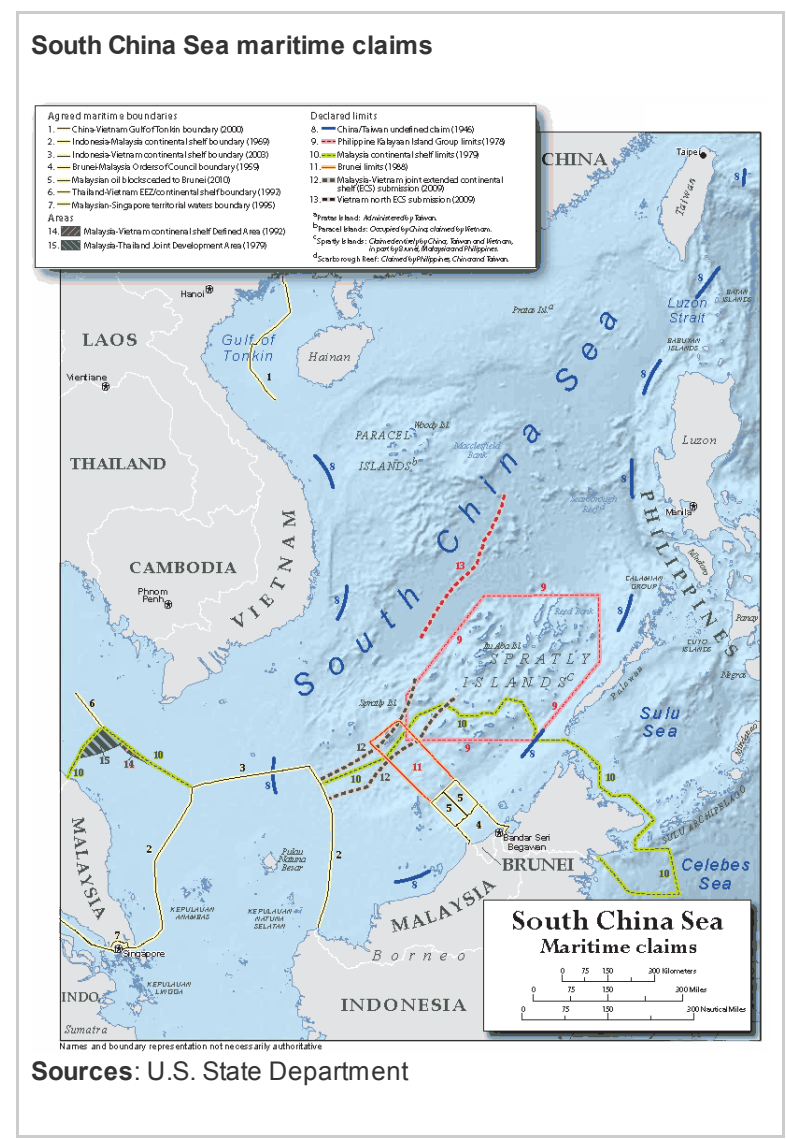

\section{Legal status}

During World War II, Japan claimed the Spratly and Paracel Islands chains. The 1951 Treaty of Peace with Japan failed to specify who would gain possession of the Spratly and Paracel Islands after Japan renounced its claims.

The United Nations Convention on the Law of the Sea (UNCLOS) has not yet resolved ownership disputes in the South China Sea. The 1982 convention created a number of guidelines concerning the status of islands, continental shelves, exclusive economic zones (EEZ), enclosed seas, and territorial limits. UNCLOS states that countries with overlapping claims must resolve them by good faith negotiation.

According to Article 121 of the third UNCLOS (1973), islands can generate their own EEZs and delimit continental shelves. Merely occupying islands does not automatically grant these rights, particularly in contested areas. The real issue is whether to consider these landmasses as rocks and islets or proper islands. According to Article 121(3) of UNCLOS, rocks "which cannot sustain human habitation or economic life of their own shall have no exclusive economic zone or continental shelf."

\section{Territorial claims}

\section{South China Sea territorial claims}

\begin{tabular}{|c|c|c|c|c|}
\hline Country & $\begin{array}{l}\text { South China } \\
\text { Sea }\end{array}$ & $\begin{array}{l}\text { Spratly } \\
\text { Islands }\end{array}$ & $\begin{array}{l}\text { Paracel } \\
\text { Islands }\end{array}$ & $\begin{array}{l}\text { Gulf of } \\
\text { Thailand }\end{array}$ \\
\hline Brunei & UNCLOS & $\begin{array}{l}\text { no formal } \\
\text { claim }\end{array}$ & no & - \\
\hline Cambodia & - & - & - & UNCLOS \\
\hline China & all* & all & all & - \\
\hline Indonesia & UNCLOS & no & no & - \\
\hline Malaysia & UNCLOS & 3 islands & no & UNCLOS \\
\hline
\end{tabular}




\begin{tabular}{|c|c|c|c|c|}
\hline Philippines & $\begin{array}{l}\text { significant } \\
\text { portions }\end{array}$ & 8 islands & no & - \\
\hline Taiwan & all* & all & all & - \\
\hline Thailand & - & - & - & UNCLOS \\
\hline Vietnam & all* & all & all & UNCLOS \\
\hline
\end{tabular}

* excluding buffer zone along littoral states (calculations for buffer unknown)

Source: U.S. Energy Information Administration

\section{Brunei}

Brunei has not made any formal claims to any of the Spratly or Paracel Islands. However, since 1985 the country has claimed a continental shelf extending to a hypothetical median with Vietnam. According to Malaysia, the 1958 U.K. Order in Council set the proper maritime boundary between Brunei and Malaysia (when both countries were British territories) at the 100 -fathom isobaths from the coast. Despite the lack of any formal claims, Brunei's continental shelf claim implies ownership of the Louisa Reef, which is technically part of the Spratly Islands archipelago. China (including Taiwan), Malaysia, Vietnam, and the Philippines have all rejected Brunei's claims to this area.

\section{Cambodia}

Cambodia claims portions of the Gulf of Thailand based upon its EEZ and the continental shelf principle, as well as its history in the Gulf. In 1982, Cambodia signed The Agreement on Historic Waters with Vietnam, setting the stage for later cooperation between the two countries. In 2006, Cambodia and Vietnam announced their intention to share the oil resources of the Gulf of Thailand. Cambodia has no such agreements with either Thailand or Malaysia. Cambodia has made no claim on the South China Sea.

\section{China}

China bases its claim to the islands on historical naval expeditions stretching back to the 15th century. In 1947, the Republic of China under the Kuomintang government submitted an official map with a "nine-dashed line" outlining the extent of Chinese territory and has continued to use this map in official correspondence. All of the sea's coastal states have ratified the 1982 UN Convention on the Law of the Sea (UNCLOS), which limits state authority to a nation's territorial waters or specially awarded exclusive economic zones (EEZs). China submitted the nine-dashed line to UNCLOS in 2009 as its claim beyond 200 nautical miles, but it is not clear whether China claims the land features within the ninedashed line and the EEZs they would generate, or the entire area within the line.

China refers to the Spratly Islands, Paracel Islands, Pratas Island, and Scarborough Reef as Nansha Qundao, Xisha Qundao, Dongsha Qundao, and Huangyan Dao, respectively, claiming these as well as all surfacing and undersea features within the nine-dashed line on Chinese SCS maps. China treats Scarborough Reef, also claimed by the Philippines, as part of partially drying Macclesfield Bank (Zhongsha Qundao). China adopted the nine dashes from Kuomintang maps drawn in 1947, resulting in Taiwan's claims coinciding largely with China's. China considers the area within the dashes to be part of Hainan Province and has referred to the maritime space therein as Chinese "territorial waters," an undefined term that does not appear to conform to standard maritime regimes permitted under international law. Chinese archeologists assert the islands in the SCS were the ancient site of fishing and merchant activities, and Chinese records note naval expeditions into the South China Sea during the Han Dynasty in A.D. 110 and the Ming Dynasty from 1403-1433. China contends the 1887 Sino-French Convention allocated all features to China east of $108 \hat{A}^{\circ} 03^{\prime} E$. China occupies several of the Spratly Islands and seized all the Paracel Islands from Vietnam in 1974. Brunei, Malaysia, the Philippines, and Vietnam dispute China's claims.

In June 2012, China announced that it was establishing a prefecture-level city named Sansha to be overseen directly by the central government on the Paracel's Woody Island (Yongxing). Sansha would administer the Paracel Islands, Spratly Islands, and Macclesfield Bank. 


\section{Indonesia}

Indonesia limits its claim in the South China Sea to the boundaries of the EEZ and

continental shelf. Indonesia claims neither the Spratly nor the Paracel Islands. However, in

1996 Indonesia conducted a large scale military exercise in the sea, citing a need to ensure

security for energy projects in the Natuna basin.

\section{Philippines}

The Philippines claimed Scarborough Reef as well as a large portion of the Spratly Islands as terra nullius (no one's land) during explorations in the SCS commencing in May 1956. It named the Spratly claim the Kalayaan (Freedom) Island Group and occupies several of the islands. It defines the Spratly Islands and Scarborough Reef as a special "regime of islands" distinct from the rest of the Philippine archipelago. China (including Taiwan), Malaysia, and Vietnam object to the Philippines' claims.

\section{Taiwan}

Taiwan, like China, asserts "historic" sovereignty over all features drawn within the dashes originally shown on a map published by the Kuomintang government in 1947-including the Spratly Islands, Paracel Islands, Pratas Island, and Scarborough Reef. Taiwan occupies several of the Spratly Islands and administers Pratas Island. Brunei, Malaysia, the Philippines, and Vietnam object to Taiwan's coincident claims with China.

\section{Thailand}

Thailand claims the Gulf of Thailand based on its EEZ and continental shelf principle. The government signed a cooperative agreement for exploration and development with Malaysia in 1979. In 1997, Thailand and Vietnam signed an agreement setting the delimitation of their respective sea boundaries. Thailand has no claim on the South China Sea.

\section{Vietnam}

Vietnam claims all of the Spratly and Paracel Islands. However, the extent of Vietnam's territorial and maritime claims in the SCS has not been delineated in text or on maps. Vietnam considers the Spratly Islands an offshore district of Khanh Hoa Province and occupies several of them. China seized all of the Paracels in 1974. Like the Chinese, Vietnamese archeologists provide their own evidence to support a long historic presence on various SCS features. Hanoi claims that since France controlled both island groups beginning in the 1930s, Vietnam succeeded to those rights after independence. Brunei, China (including Taiwan), Malaysia, and the Philippines dispute Vietnam's claims.

In May 2009, Vietnam and Malaysia jointly submitted their territorial claims on the South China Sea to the UN Commission on the Limits of the Continental Shelf. In June 2012, Vietnam passed a maritime law claiming juris diction over the Paracel and Spratly Islands and demanding that all foreign naval ships register with Vietnamese authorities.

\section{Regional conflicts and mediation efforts}

The Association of Southeast Asian Nations (ASEAN) has emerged as an important forum for dialogue among South China Sea claimants. Although ASEAN does not include China and Taiwan, a number of working groups with China and Taiwan have been held on issues with the potential to foster the relationships necessary to resolve the more contentious issues in the region.

Indonesia hosted the first dialogue workshop in 1990 and has since taken a leading role in diplomatic initiatives and cooperative agreements to resolve SCS issues. However, the countries failed to pass any resolution during the last ASEAN meeting in Jakarta in 2012.

\section{Notes}

- Data presented in the text are the most recent available as of February 7, 2013.

- Data are EIA estimates unless otherwise noted. 


\section{Sources}

- Association of Southeast Asian Nations

- Bangkok Post

- BBC Monitoring Asia Pacific

- Business Monitor International

- Cedigaz

- Center for Strategic and International Studies

- China National Offshore Oil Corporation

- Danish Institute for International Studies

- Economist Intelligence Unit

- ESRI

- FACTS Global Energy

- Financial Times

- HuskyEnergy

- IHS/Edin

- IHS/Global Insight

- Institute of Southeast Asia Studies

- International Crisis Group

- International Energy Agency

- International Hydrographic Organization

- Lloyd's List Intelligence Tanker Tracking Service

- New Straits Times (Malaysia)

- PFC Energy

- South China Morning Post

- The International Herald Tribune

- The New York Times

- The Straits Times (Singapore)

- U.S. Department of State

- U.S. Energy Information Administration

- U.S. Geological Survey (USGS)

- United Nations

- Xinhua News 